\title{
PENGARUH JUMLAH PENDUDUK DAN PENGELUARAN PEMERINTAH TERHADAP PENDAPATAN ASLI DAERAH DI PROVINSI SUMATERAUTARA
}

\author{
IKHWANUDDIN HARAHAP \\ IAIN PADANGSIDIMPUAN
}

Jalan T. Rizal Nurdin Km. 4,5 Sihitang, Padangsidimpuan

Email: ikhwanuddinharahap@gmail.com

\begin{abstract}
ABSTRAK
Latar belakang masalah dalam penelitian ini adalah terjadinya fenomena penurunan pendapatan asli daerah (PAD) pada tahun 2001, 2005, 2009, dan tahun 2016, pada tahun yang sama jumlah penduduk meningkat, dan pengeluaran pemerintah juga mengalami peningkatan, fenomena ini tidak sesuai dengan teori yang mengatakan bahwa PAD merupakan indikator kesiapan daerah yang dapat mendorong pemerintah, dunia usaha, dan masyarakat daerah mengenai pengenaan pajak dan retribusi yang sesuai dengan tingkat pendapatan masyarakat yang akhirnya dapat meningkatkan PAD. Rumusan masalah dalam penelitian ini adalah apakah terdapat pengaruh jumlah penduduk dan pengeluaran pemerintah terhadap PAD di Provinsi Sumatera Utara secara parsial maupun simultan. Pembahasan penelitian ini berkaitan dengan jumlah penduduk, pengeluaran pemerintah dan pendapatan asli daerah. Sehubungan dengan ini pendekatan yang dilakukan adalah teori-teori yang berkaitan dengan bidang tersebut. Penelitian inimerupakan penelitian kuantitatif deskriptif, sampel yang digunakan sebanyak 30 sampel dengan desain purposive sampling, data diperoleh melalui situs www.bps.go.id. Pengujian dalam penelitian ini adalah dengan menggunakan program komputer Eviews Versi 9.o.

Hasil penelitian menunjukkan bahwa secara parsial tidak terdapat pengaruh jumlah penduduk terhadap PAD di Provinsi Sumatera Utara. Secara simultan terdapat pengaruh jumlah penduduk dan pengeluaran pemerintah terhadap PAD di Provinsi Sumatera Utara. Pengaruh jumlah penduduk dan pengeluran pemerintah terhadap PAD di Provinsi Sumatera Utara sebesar 92,45\% sedangkan sisanya sebesar 7,55\% dipengaruhi faktor lain yang tidak dimasukkan dalam penelitian.
\end{abstract}

Kata Kunci : Jumlah Penduduk, Pengeluaran Pemerintah DanPendapatan Asli Daerah

\section{ABSTRACT}

The background of the problem in this study was the occurrence of the phenomenon of decreasing regional original income (PAD) in 2001, 2005, 2009, and in 2016, in the same year the population increased, this phenomenon is not in accordance with the theory which says that PAD is an indicator of regional readiness that can encourage governments, businesses, and local communities regarding the imposition of taxes and levies that are in accordance with the level of income of the people who can ultimately increase PAD. The formulation of the problem in this study is whether there is an influence of the population and government expenditure on PAD in North Sumatra Province partially or 
PENGARUH JUMLAH PENDUDUK DAN PENGELUARAN PEMERINTAH TERHADAP PENDAPATAN ASLI DAERAH DI PROVINSI SUMATERAUTARA

Ikhwanuddin Harahap

simultaneously. The discussion of this study relates to population, government expenditure and local revenue. In connection with this the approach taken is the theories relating to the field. This research is a quantitative descriptive study, the sample used was 30 samples with a purposive sampling design, data obtained through the site www.bps.go.id. The test in this study is to use the computer program Eviews Version 9.0.

The results showed that there was no partial effect on the number of residents of PAD in North Sumatra Province. Simultaneously there are influences of population and government expenditure on PAD in North Sumatra Province. The influence of population and government expenditure on PAD in North Sumatra Province amounted to $92.45 \%$ while the remaining $7.55 \%$ was influenced by other factors not included in the study.

Keywords: Population, Government Expenditures and Regional Original Income

\section{PENDAHULUAN}

Negara Indonesia merupakan negara kesatuan yang menerapkan otonomi daerah. Otonomi daerah merupakan peralihan sistem pembangunan dari sentralisasi menjadi desentralisasi. Sistem ini muncul untuk menjadikan pembangunan daerah menjadi lebih baik, karena pada sistem desentralisasi pemerintah daerah diberikan keleluasaan dalam mengelolah sendiri keuangan daerahnya. Apabila sistem keuangan diatur sendiri oleh daerah masing-masing akan mempermudah daerahnya membangun berbagai sarana publik serta upaya meningkatkan kesejahteraan masyarakat daerah lebih mudah dan efektif, sehingga berbagai masalah kemiskinan, pengangguran dan ketimpangan distribusi pendapatan dapat terselesaikan.

Masalah dalam penelitian ini adalah terjadinya fenomena penurunan pendapatan asli daerah (PAD) pada tahun 2001, 2005, 2009, dantahun 2016 sebesar Rp423.100.000.000, Rp1.108.000.000.000, Rp2.016.070.000.000 danRp4.630.000.000.000, pada tahun yang sama jumlah penduduk meningkat sebesar11.722.000.000jiwa,12.327.000.000 jiwa, 13.248.000.000 jiwa, 14.103.000.000 jiwa,danpengeluaran pemerintah meningkat sebesar Rp916.200.000.000,Rp1.830.600.000.000,Rp3.444.400.000.000, dan Rp9.950.844.000.000, fenomena ini tidak sesuai dengan teori yang mengatakan bahwa PAD merupakan indikator kesiapan daerah yang dapat mendorong pemerintah, dunia usaha, dan masyarakat daerah mengenai pengenaan pajak dan 
retribusi yang sesuai dengan tingkat pendapatan masyarakat yang akhirnya dapat meningkatkan PAD.

\section{LANDASAN TEORI}

Pengertian Pendapatan Asli Daerah

Pemerintah daerah terdiri dari pemerintah provinsi dan kabupaten/kota sebagaimana yang dinyatakan dalam Undang-Undang No. 22 Tahun 1999 yang mengatakan bahwa tidak dikenal lagi pembagian daerah tingkat I dan II. Pemerintah daerah hanya dibedakan menjadi pemerintah pusat dan kabupaten/kota, sehingga kota madya telah dihapuskan, pemerintah pusat yang menarik pajak untuk membiayai kegiatannya, maka pemerintah daerah juga menarik pajak untuk membiayai kegiatan pemerintah daerah yang dapat menunjang peningkatan pendapatan asli daerah.

Menurut Undang-Undang no. 33 tahun 2004 pendapatan daerah adalah hak pemeritah daerah yang diakui sebagai penambah nilai kekayaan bersih dalam periode tahun yang bersangkutan. Pendapatan asli daerah menurut UndangUndang no. 32 tahun 2004 adalah pendapatan daerah yang bersumber dari pajak daerah, retribusi daerah, hasil pengelolaan kekayaan yang dipisahkan, dan lainlain pendapatan asli daerah yang sah (Phaureula, 2018).

Sumber-Sumber Pendapaan Asli Daerah

Pajak Daerah

Pajak daerah, yang selanjutnya disebut pajak, adalah iuran wajib yang dilakukan oleh orang pribadi atau badan kepada daerah tanpa imbalan yang langsung yang seimbang, yang dapat dipaksakan berdasarkan peraturan perundang-undangan yang berlaku, yang digunakan untuk membiayai penyelenggaraan pemerintah daerah dan pembangunan daerah (Himpunan Peraturan Perundang-undangan, 2009). Pajak daerah dipergunakan untuk membiayai pembangunan yang diupayakan pemerintah untuk kesejahteraan masyarakat melalui undang-undang yang dikeluarkan oleh pemerintah dan masyarakat ikut serta dalam pembangunan tersebut melalui pembayaran pajak 
PENGARUH JUMLAH PENDUDUK DAN PENGELUARAN PEMERINTAH TERHADAP PENDAPATAN ASLI DAERAH DI PROVINSI SUMATERAUTARA

Ikhwanuddin Harahap

daerah. Menurut Davey pajak daerah adalah sebagai berikut: Pajak daerah adalah pajak yang dipungut pemerintah daerah dengan pengaturan dari daerah itu sendiri, dipungut berdasarkan peraturan nasional tetapi penetapan tarifnya dilakukan oleh pemerintah daerah, dan ditetapkan atau dipungut oleh pemerintah daerah (Himpunan Peraturan Perundang, 2009).

Sehingga dapat dikatakan bahwa pajak daerah merupakan sumber pendapatan daerah yang diatur oleh pemerintah daerah dan diperuntukkan untuk menunjang pendapatan asli daerah. Diantara jenis-jenis pajak daerah dan tariff pajak sebagai berikut:

Jenis pajak daerah yang dipungut oleh provinsi:

(1). Pajak kendaraan bermotor dan kendaraan di atas air (PKB-KAA) dengan tarif $5 \%$.

(2). Bea balik nama kendaraan bermotor dan kendaraan di atas air (BBNKBKAA) dengan tarif $10 \%$.

(3). Pajak bahan bakar kendaraan bermotor (PBBKB) dengan tariff 5\%.

(4). Pajak pengambilan dan pemanfaatan air bawah tanah dan air permukaan (P3ABT dan AP) dengan tarif $20 \%$.

Jenis pajak daerah yang dipungut kabupaten/kota:

(1). Pajak hotel dengan tarif $10 \%$.

(2). Pajak restoran dengan tarif $10 \%$.

(3). Pajak hiburan dengan tarif $35 \%$.

(4). Pajak reklame dengan tarif $25 \%$.

(5). Pajak penerangan jalan dengan tariff $10 \%$.

(6). Pajak pengambilan bahan galian golongan $\mathrm{C}$ dengan tarif $20 \%$.

(7). Pajak parkir dengan tarif 20\%. (Himpunan Peraturan Perundang-undangan, 2009) 
Retribusi Daerah

Retribusi daerah yang selanjutnya disebut retribusi, adalah pungutan daerah sebagai pembayaran atas jasa atau pemberian izin tertentu yang khusus disediakan dan atau diberikan oleh pemerintah daerah untuk kepentingan orang pribadi atau badan (Hanif Nurcholis, 2014). Menurut UU No. 34 Tahun 2000 retribusi daerah adalah pungutan daerah sebagai pembayaran atas jasa atau pemberian izin tertentu yang khusus disediakan oleh pemerintah daerah untuk kepentingan orang pribadi atau badan (Hanif Nurcholis, 2014).

Dari pemaparan di atas ditarik kesimpulan bahwa retribusidiperuntukkan pada pelaku ekonomi yang memperoleh pendapatan melalui bidang pemberian jasa atau perizinan dalam suatu usaha, sehingga dapat menambah sumber pendapatan asli daerah. Misalnya surat keterangan mendirikan bangunan milik pribadi atau suatu badan tertentu.

\section{METODE PENELITIAN}

Jenis penelitian yang digunakan peneliti adalah jenis penelitian kuantitatif, Populasi dalam penelitian ini adalah seluruh data yang dipublikasikan di BPS yaitu data jumlah penduduk, pengeluaran pemerintah dan pendapatan asli daerah di Provinsi Sumatera Utara periode 1980-2016. Teknik pengambilan sampel yang digunakan dalam penelitian adalah teknik purposive sampling, yaitu teknik pengumpulan sampel yang dilakukan berdasarkan karakteristik yang ditetapkan terhadap elemen populasi target yang disesuaikan dengan tujuan atau masalah penelitian (Nanang Martono, 2011). Adapun jumlah sampel dalam penelitian ini adalah sebesar 30 sampel. Untuk itu sampel yang diambil dari populasi harus betul-betul repsetentatif (mewakili) (Sugiono, 2008).

\section{TeknikPengumpulan Data}

Adapun teknik pengumpulan data yang dilakukan pada penelitian ini adalah metode dokumentasi yaitu melalui pengumpulan data sekunder dengan kepustakaan dan manual (Nur Asnawi Dan Masyhuri, 2011).

\section{Analisis Data}


PENGARUH JUMLAH PENDUDUK DAN PENGELUARAN PEMERINTAH TERHADAP PENDAPATAN ASLI DAERAH DI PROVINSI SUMATERAUTARA

Ikhwanuddin Harahap

Untuk memperoleh hasil penelitian yang sesuai dengan tujuan penelitian, maka teknik analisis data dalam penelitian ini akan diolah dan dianalisis dengan menggunakan program eviews 9.0. Adapun uji yang digunakan dalam menganalisis data dalam penelitian ini adalah, AnalisisDeskriptif, UjiNormalitas, Uji LinieritaS, UjiAumsiKlasiK, Analisis Regresi Berganda.

\section{HASIL PENELITIAN}

\section{Analisis Deskriptif}

Adapun analisis deskriptif dalam penelitian ini menggunakan menu deskriptif dengan hasil sebagai berikut.

\section{Hasil Analisis Deskriptif}

\begin{tabular}{|l|l|l|l|}
\hline & PAD & JP & PP \\
\hline Mean & 1502059. & 11964,77 & 2536592. \\
\hline Median & 761350,0 & 11868,50 & 968750,0 \\
\hline Maximum & 5257670. & 14103,00 & 9950844. \\
\hline Minimum & 56724,00 & 9902,000 & 205200,0 \\
\hline Std. Dev. & 1704355. & 1212,224 & 3065436. \\
\hline Observations & 30 & 30 & 30 \\
\hline
\end{tabular}

Sumber: Output Eviews versi 9

Berdasarkan tabel IV.3 di atas dapat dilihat bahwa variabel pendapatan asli daerah dengan jumlah data $(\mathrm{N})$ sebanyak 30 mempunyai nilai mean sebesar1.502.059juta dengan nilai minimum sebesar56.724,00jutadan nilai maksimum sebesar5.257.670juta. Variabel jumlah penduduk dengan jumlah data (N) sebanyak 30 mempunyai nilai meansebesar11.964,77jutadengan nilai minimum sebesar9.902,000jutadan nilai maksimum sebesar14.103,00juta.Variabel pengeluaran pemerintah dengan jumlah data $(\mathrm{N})$ sebanyak 30 mempunyai nilai mean sebesar2.536.592jutadengan nilai minimum sebesar205.200,0jutadan nilai maksimum sebesar9.950.844juta.Berdasarkangambaran keseluruhan sampel yang berhasil dikumpulkan telah memenuhi syarat untuk diteliti.

\section{Uji Normalitas}

Untuk melihat apakah data berdistribusi normal dengan menggunakan Jarque Beraadalah dengan melihat angka probabilitas dengan menggunakan $\alpha=$ 
5\%, apabila nilai probabilitas $>0,05$ maka data berdistribusi normal. Hasil uji normalitas dapat dilihat sebagai berikut:

\section{Hasil Uji Normalitas}

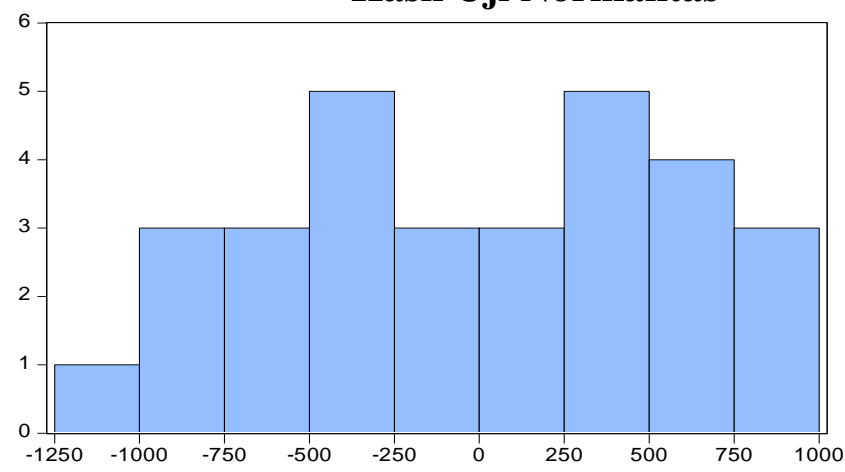

Sumber: Output Eviews versi 9

\begin{tabular}{|c|c|}
\hline \multicolumn{2}{|c|}{$\begin{array}{l}\text { Series: Residuals } \\
\text { Sample } 19872016 \\
\text { Observations } 30\end{array}$} \\
\hline Mean & $-1.29 e-13$ \\
\hline Median & 51.70859 \\
\hline Maximum & 965.6524 \\
\hline Minimum & -1193.975 \\
\hline Std. Dev. & 607.2727 \\
\hline Skewness & -0.220802 \\
\hline Kurtosis & 1.921682 \\
\hline Jarque-Bera & 1.697228 \\
\hline Probability & 0.428008 \\
\hline
\end{tabular}

Berdasarkan gambar IV.1 di atas, diketahui bahwa nilai probability Jarque Bera sebesar 0,428008. Jika nilai ini dibandingkan dengan tingkat signifikan $5 \%$ maka0,428008 >0,05. Dengan demikian data penelitian ini yang terdiri dari Pendapatan Asli Daerah (Y), Jumlah Penduduk (X1), Pengeluaran Pemerintah (X2) dapat dikatakan berdistribusi normal.

\section{Uji Linieritas}

Hasil uji linieritas dapat dilihat sebagai berikut:

\section{Hasil Uji Linieritas}

\begin{tabular}{|c|c|c|c|}
\hline Ramsey RESET & & & \\
\hline Equation: UNTI] & & & \\
\hline Specification: PA & JP PP & & \\
\hline Omitted Variable & uares of fit & d values & \\
\hline & Value & df & Probability \\
\hline t-statistic & 5,269926 & 26 & 0,0001 \\
\hline F-statistic & 27,77212 & $(1,26)$ & 0,0001 \\
\hline Likelihood ratio & 21,79976 & 1 & 0,0001 \\
\hline
\end{tabular}


PENGARUH JUMLAH PENDUDUK DAN PENGELUARAN PEMERINTAH TERHADAP PENDAPATAN ASLI DAERAH DI PROVINSI SUMATERAUTARA

Ikhwanuddin Harahap

Sumber: Output Eviews versi 9

Berdasarkan tabel IV.4 di atas uji linieritas dapat diketahui dari nilai $p$ value sebesar 0,0001 karena signifikan $<0,05$ maka dapat dinyatakan antara variabel jumlah penduduk, pengeluaran pemerintah dan pendapatan asli daerah terdapat hubungan yang linier.

\section{Uji Asumsi Klasik}

a. Uji Multikolinearitas

Hasil uji multikolinearitas dapat dilihat sebagai berikut:

Hasil Uji Multikolinearitas

\begin{tabular}{|l|l|l|l|}
\hline Variable & $\begin{array}{c}\text { Coefficient } \\
\text { Variance }\end{array}$ & $\begin{array}{c}\text { Uncentered } \\
\text { VIF }\end{array}$ & \multicolumn{1}{|c|}{$\begin{array}{c}\text { Centered } \\
\text { VIF }\end{array}$} \\
\hline C & 2,444412 & 311,0937 & NA \\
\hline JP & 19650,01 & 362,1064 & 3,557802 \\
\hline PP & 0,003073 & 6,077925 & 3,557802 \\
\hline
\end{tabular}

Sumber: Output Eviews versi 9

Berdasarkan tabel IV.5 di atas dapat diketahui nilai VIF dari variabel jumlah pendudukdan pengeluaran pemerintah < dari $10(3,557802<10)$, artinya tidak terjadi multikolonearitas terhadap data.

\section{Uji Autokorelasi}

Hasil uji autokorelasi dapat dilihat sebagai berikut:

\section{Hasil Uji Autokorelasi}

\begin{tabular}{|llll|}
\hline \multicolumn{4}{|l|}{ Breusch-Godfrey Serial Correlation LM Test: } \\
\hline \hline F-statistic & 0,280315 & Prob. F(2,25) & 0,7579 \\
Obs*R-squared & 0,658000 & Prob. Chi-Square(2) & 0,7196 \\
\hline
\end{tabular}

Sumber: Output Eviews versi 9 
Metode ini didasarkan pada nilai Obs*R-Squeared, jika probabilitas dari Obs*R-Squeared melebihi tingkat kepercayaan $(\alpha)$, maka $\mathrm{H}_{0}$ diterima.Artinya tidak terdapat masalah autokorelasi. Dari hasil analisis di atas bahwa 0,658000>0,05 maka dapat disimpulkan bahwa tidak terdapat masalah autokorelasi terhadap data.

\section{Uji Heterokedastisitas}

Hasil uji heterokedastisitas dapat dilihat sebagai berikut:

Hasil Uji White Heteroskedastisitas

\begin{tabular}{|llll|}
\hline \multicolumn{4}{l}{ Heteroskedasticity Test: Breusch-Pagan-Godfrey } \\
\hline \hline F-statistic & 0,129548 & Prob. F(2,27) & 0,8790 \\
Obs*R-squared & 0,285148 & Prob. Chi-Square(2) & 0,8671 \\
Scaled explained SS & 1,639631 & Prob. Chi-Square(2) & 0,4405 \\
\hline
\end{tabular}

Sumber: Output Eviews versi 9

Berdasarkan tabel IV.7 di atas, diketahui bahwa nilai prob. Obs*R-squared (Y) sebesar 0,285148. Jika nilai ini dibandingkan dengan tingkat signifikan $5 \%$ $(0,285148>0,05)$. Dengan demikian jumlah penduduk $(\mathrm{X} 1)$, dan pengeluaran pemerintah (X2) tidak terjadi heteroskedastisitas pada model regresi.

\section{Analisis Regresi Berganda}

Hasil analisis regresi berganda dapat dilihat sebagai berikut:

\section{Hasil Analisis Regresi Berganda}

\begin{tabular}{l} 
Dependent Variable: PAD \\
Method: Least Squares \\
Date: 03/18/18 Time: 06:05 \\
Sample: 19872016 \\
Included observations: 30 \\
\hline \hline Variable $\quad$ Coefficient $\quad$ Std. Errort-Statistic Prob.
\end{tabular}


PENGARUH JUMLAH PENDUDUK DAN PENGELUARAN PEMERINTAH TERHADAP PENDAPATAN ASLI DAERAH DI PROVINSI SUMATERAUTARA

Ikhwanuddin Harahap

\begin{tabular}{|lllll|}
\hline \hline C & -2651676. & 1562274. & $-1,697318$ & 0,1011 \\
JP & 252,3164 & 140,1785 & 1,799965 & 0,0831 \\
PP & 0,447383 & 0,055433 & 8,070640 & 0,0000 \\
\hline \hline R-squared & 0,924562 & Mean dependent var & 1502059. \\
Adjusted R-squared & 0,918974 & S.D. dependent var & 1704355. \\
S.E. of regression & 485145,8 & Akaike info criterion & 29,11693 \\
Sum squared resid & 6.355512 & Schwarz criterion & 29,25705 \\
Log likelihood & $-433,7539$ & Hannan-Quinn criter. & 29,16175 \\
F-statistic & 165,4550 & Durbin-Watson stat & 2,157596 \\
Prob(F-statistic) & 0,000000 & & \\
\hline \hline
\end{tabular}

Sumber: Output Eviews versi 9

Berdasarkan hasil uji regresi pada tabel IV.8 di atas, maka persamaan analisis regresi linear berganda penelitian ini adalah:

$$
\begin{gathered}
\mathrm{PAD}=\beta_{0}+\beta_{1} \mathrm{JP}+\beta_{2} \mathrm{PP}+\mathrm{e} \\
\mathrm{PAD}=-2651676+252,3164 \mathrm{JP}+0,447383 \mathrm{PP}+\mathrm{e}
\end{gathered}
$$

Persamaan hasil regresi tersebut dapat dijelaskan sebagai berikut:

a. Nilai konstan sebesar -2651676 artinya apabila JP dan PP bernilai 0, maka PAD sebesar -2651676 juta.

b. Nilai koefisien regresi pada JP sebesar 252,3164, artinya jika JP bertambah 1 juta sedangkan PP tetap maka PAD mengalami peningkatan sebesar 252,3164 juta. Koefisien bernilai positif itu artinya terjadi hubungan yang positif antara JP dan PAD. JP yang meningkat akan meningkatkan PAD di Provinsi Sumatera Utara.

c. Nilai koefisien regresi pada PP sebesar 0,447383, artinya jika PP bertambah 1 juta sedangkan JP tetap maka PAD mengalami peningkatan sebesar 0,447383 
juta. Koefisien berniai positif artinya terjadi hubungan yang positif antara PP dengan PAD. PP yang meningkat akan meningkatkan PAD di Provinsi Sumatera Utara.

\section{Uji Hipotesis}

\section{Uji Koefisien Determinasi $\left(\mathbf{R}^{2}\right)$}

Hasil Uji Koefisien Determinasi $\left(\mathbf{R}^{2}\right)$

\begin{tabular}{|l|l|}
\hline R-squared & 0,924562 \\
\hline Adjusted R-squared & 0,918974 \\
\hline S.E. of regression & 485145,8 \\
\hline Sum squared resid & 6,355512 \\
\hline Log likelihood & $-433,7539$ \\
\hline F-statistic & 165,4550 \\
\hline Prob(F-statistic) & 0,000000 \\
\hline
\end{tabular}

Sumber: Output Eviews versi 9

Berdasarkan hasil ujiKoefisien Determinasi $\left(\mathrm{R}^{2}\right)$ pada tabel IV.9 di atas menunjukkan bahwa nilai $R$-square sebesar 0,924562menunjukkan bahwa proporsi pengaruh jumlah penduduk dan pengeluaran pemerintah mempengaruhi pendapatan asli daerah sebesar $92,45 \%$ sedangkan sisanya 7,55\% dipengaruhi olehvariabellain yang tidak ada didalam model regresi penelitian ini.

\section{Uji Parsial (Uji t)}

Uji t digunakan untuk melihat seberapa jauh pengaruh satu variabel independen secara individual dalam menjelaskan variasi variabel dependen. Uji ini akan membandingkan nilai $p$-value dengan $\alpha$. Jika $p$-value $<\alpha$ maka $\mathrm{H}_{0}$ ditolak dan sebaliknya apabila $p$-value $>\alpha$ maka $\mathrm{H}_{\mathrm{a}}$ diterima. Hasil uji t dapat dilihat pada tabel IV.8 sebagai berikut:

\section{Hasil Uji parsial (Uji t)}

\begin{tabular}{|c|c|c|c|}
\hline Variable & CoefficientStd. Error & t-Statistic & Prob. \\
\hline C & -2651676.1562274 & $-1,697318$ & 0,1011 \\
\hline
\end{tabular}


PENGARUH JUMLAH PENDUDUK DAN PENGELUARAN PEMERINTAH TERHADAP PENDAPATAN ASLI DAERAH DI PROVINSI SUMATERAUTARA

Ikhwanuddin Harahap

\begin{tabular}{|lcccc|} 
JP & 252,3164 & 140,1785 & 1,799965 & 0,0831 \\
PP & 0,447383 & 0,055433 & 8,070640 & 0,0000 \\
\hline \hline R-squared & 0,924562 & Mean dependent var & 1502059. \\
Adjusted R-squared & 0,918974 & S.D. dependent var & 1704355. \\
S.E. of regression & 485145,8 & Akaike info criterion & 29,11693 \\
Sum squared resid & 6,355512 & Schwarz criterion & 29,25705 \\
Log likelihood & $-433,7539$ & Hannan-Quinn criter. & 29,16175 \\
\hline
\end{tabular}

Sumber: Output Eviews versi 9

Berikut merupakan hasil uji t dari masing-masing variabel bebas:

1) Jumlah Penduduk

Berdasarkan tabel IV.10 diketahui nilai prob. t-statistik dari jumlah penduduk sebesar 0,0831>0,05. hasil ini berarti bahwa jumlah penduduk tidak berpengaruh terhadap pendapatan asli daerah di Provinsi Sumatera Utara.

2) Pengeluaran pemerintah

Berdasarkan tabel IV.10diketahui nilai prob. t-statistik dari Pengeluaran pemerintah sebesar $0,0000<$ dari 0,05 . Hasil ini berarti bahwa Pengeluaran pemerintah berpengaruh terhadap pendapatan asli daerah di Provinsi Sumatera Utara.

Adapun apabila dilihat dari t-statistik hasil analisis uji t yaitu:

1). Pengaruh jumlah penduduk terhadap PAD dinyatakan dengan jumlah penduduk t-hitung sebesar 1,799965, dan nilai t-tabel dengan nilai signifikan $\alpha=$ 0,05 dan $\mathrm{df}=(\mathrm{n}-\mathrm{k})$, sehingga $\mathrm{df}=(30-3)=27$, jadi nilai t-tabel adalah sebesar 1,70113 dan dapat ditarik kesimpulan bahwa nilai t-hitung $>t$-tabel 1,799965>1,70113 maka jumlah penduduk berpengaruh terhadap PADdi Provinsi Sumatera Utara.

2). Pengaruh pengeluaran pemerintah terhadap $P A D \quad t$-statistik $>t$-tabel $(8,070640>1,70113)$ maka dapat ditarik kesimpulan bahwa pengeluaran pemerintah berpengaruh terhadap PAD di Provinsi Sumatera Utara. 
Uji Simultan (Uji F)

\section{Hasil Uji Simultan (Uji F)}

\begin{tabular}{|lr|}
\hline F-statistic & 165,4550 \\
Prob(F-statistic) & 0,000000 \\
\hline & Sumber: Output Eviews versi 9
\end{tabular}

Hasil uji F dapat dilihat pada tabel IV.11 di atas, Uji F digunakan untuk melihat pengaruh variabel-variabel independen secara keseluruhan tentang variabel dependen. Uji ini akan membandingkan nilai $p$-value dengan $\alpha$. Jika $p$ value $<\alpha$ maka $\mathrm{H}_{0}$ ditolak dan sebaliknya jika $p$-value $>\alpha$ maka $\mathrm{H}_{\mathrm{a}}$ diterima, dari hasil penelitin ini diperoleh $0,000000<0,05$ sehingga $\mathrm{H}_{0}$ ditolak dan dapat disimpulkan bahwa, semua variabel independen yang terdiri dari jumlah penduduk(X1), pengeluaran pemerintah (X2) berpengaruh secara simultan terhadap pendapatan asli daerah di Provinsi Sumatera Utara.

\section{DAFTAR PUSTAKA}

Phaureula Artha Wulandari Dan Emy Iryanie, Pajak Daerah Dalam Pendapatan Asli Daerah, Yogyakarta, DEEPUBLISH, 2018

Himpunan Peraturan Perundang-undangan Lengkap, Pajak Daerah Dan Retribusi Daerah, Bandung, Fokus Media, 2009

Hanif Nurcholis, Teori Dan Praktik Pemerintahan Dan Otonomi Daerah, Jakarta, Grasindo, 2005

Nanang Martono, Metodologi Penelitian Kuantitatif, Jakarta, PT. RajaGrafindo Persada, 2011

Nur Asnawi Dan Masyhuri, Metodologi Riset Manajemen Pemasaran, Malang, UIN-Mailiki Pres, 2011. 